\title{
Modulation of the virus-receptor interaction by mutations in the V5 loop of feline immunodeficiency virus (FIV) following in vivo escape from neutralising antibody
}

\author{
Brian J Willett*, Martin Kraase, Nicola Logan, Elizabeth L McMonagle, Ayman Samman and Margaret J Hosie
}

\begin{abstract}
Background: In the acute phase of infection with feline immunodeficiency virus (FIV), the virus targets activated CD4+ T cells by utilising CD134 (OX40) as a primary attachment receptor and CXCR4 as a co-receptor. The nature of the virusreceptor interaction varies between isolates; strains such as GL8 and CPGammer recognise a "complex" determinant on CD134 formed by cysteine-rich domains (CRDs) 1 and 2 of the molecule while strains such as PPR and B2542 require a more "simple" determinant comprising CRD1 only for infection. These differences in receptor recognition manifest as variations in sensitivity to receptor antagonists. In this study, we ask whether the nature of the virus-receptor interaction evolves in vivo.

Results: Following infection with a homogeneous viral population derived from a pathogenic molecular clone, a quasispecies emerged comprising variants with distinct sensitivities to neutralising antibody and displaying evidence of conversion from a "complex" to a "simple" interaction with CD134. Escape from neutralising antibody was mediated primarily by length and sequence polymorphisms in the V5 region of Env, and these alterations in V 5 modulated the virus-receptor interaction as indicated by altered sensitivities to antagonism by both anti-CD134 antibody and soluble CD134.

Conclusions: The FIV-receptor interaction evolves under the selective pressure of the host humoral immune response, and the V5 loop contributes to the virus-receptor interaction. Our data are consistent with a model whereby viruses with distinct biological properties are present in early versus late infection and with a shift from a "complex" to a "simple" interaction with CD134 with time post-infection.
\end{abstract}

\section{Background}

Infection with feline immunodeficiency virus (FIV) results in a progressive immune-dysfunction characterized by a gradual decline in helper (CD4+) T lymphocytes. Clinical signs include non-resolving gingivitisstomatitis, wasting, cachexia, neuropathological deficits, and an increased incidence of malignancy [1-9]. In the United Kingdom alone there are approximately 10 million domestic cats[10] with a seroprevalence approaching $5 \%[6]$, this equates to approximately 0.5 million FIV-

\footnotetext{
* Correspondence: b.willett@vet.gla.ac.uk

${ }^{1}$ Retrovirus Research Laboratory, Institute of Comparative Medicine, Faculty of Veterinary Medicine, University of Glasgow, Bearsden Road, Glasgow G61 1QH, UK

Full list of author information is available at the end of the article
}

infected cats. Given the similarities between the clinical outcomes of infection with FIV and the human immunodeficiency virus (HIV), FIV infection of the domestic cat is established as a valuable non-primate model for AIDS in humans, providing insights into the likely efficacy of potential vaccine strategies and facilitating the exploration of novel therapeutic interventions[11,12]. The primate lentiviruses use CD4 as a primary receptor [13-15], and the restricted expression of CD4 in vivo targets the virus preferentially to T-helper $\left(\mathrm{T}_{\mathrm{h}}\right)$ lymphocytes and cells of the monocyte/macrophage lineage. However, CD4-expression alone is insufficient to confer susceptibility to infection with HIV, which also requires co-receptors, principally the chemokine receptors CXCR4 and 
CCR5 [16-19](reviewed in [20]). In HIV infection, disease progression is often accompanied by a shift in the coreceptor usage of the dominant variants in the peripheral circulation, from CCR5 (and occasionally CCR3)-dependent to CXCR4-dependent viruses [21-25](reviewed in [26]). In contrast to the primate lentiviruses, all primary isolates of FIV isolated from domestic cats tested to date utilise CD134 (OX40) as a primary attachment receptor [27-29] and CXCR4 as a co-receptor [30-34] (CCR5 does not mediate infection with FIV[35]). Recent data have revealed two distinct modes of interaction between FIV and its primary receptor CD134 (reviewed in[36]). FIV strains such as GL8 and CPG require determinants in both CRD1 and CRD2 of CD134 for infection while at the other extreme, B2542 and PPR are capable of infecting via an interaction with CRD1 alone[27,37]. Preliminary analyses of the modes of CD134 interaction of diverse strains of FIV have indicated that GL8 and B2542 represent two extremes of a spectrum, with many viruses displaying an intermediate dependency on determinants within CRD2 for infection $[27,36]$. As yet there are no data to discern whether differences in the nature of the Env-CD134 interaction contribute to pathogenicity in vivo; however, there is a correlation between the nature of the EnvCD134 interaction and sensitivity to antagonism by soluble CD134L and anti-CD134[38,39].

Previously, we proposed that early infection with FIV may be dominated by viruses with a complex, high affinity interaction with CD134 (reviewed in $[36,40]$ ) and which target cells where CD134 is abundant (activated CD4+ T cells[29]) and which have a restricted cell tropism. With disease progression, variants would emerge that have a less complex, low affinity interaction with CD134 and a propensity for CD134-independent infection through a direct interaction with CXCR4. Accordingly the cell tropism of the virus may shift with disease progression leading to viral dissemination into novel cellular compartments. These variants may be controlled by the humoral immune response in early infection, but would become more abundant as the disease progressed through escape from neutralisation and exhaustion of the humoral immune response. In this study we examined the diversity of viral variants in the blood of a cat infected with a molecular clone of FIV strain GL8 $\left(\mathrm{GL}_{414}\right)$. As a first step towards understanding the process of viral evolution in FIV infection, we characterised the biological properties of the viral variants from this animal and demonstrated the emergence of variants with distinct receptor usages and sensitivities to neutralising antibodies. Moreover, we demonstrate for the first time that mutations in the V5 loop, a primary target for escape from neutralisation may modulate the virus-receptor interaction, suggesting that escape from neutralising antibodies may drive alterations in the virus-receptor interaction.

\section{Methods}

\section{Preparation of genomic DNAs}

Peripheral blood mononuclear cells (PBMC) were collected at post mortem (p.m.) from a cat (A613) infected for 322 weeks with the 414 molecular clone of FIVGL8[41]. A613 was one of a group of 3 specific pathogenfree cats infected with the 414 clone. Following infection, the virus achieved a high proviral load in PBMC and triggered a depletion of CD4+ lymphocytes and the expansion of an activated CD8+ lymphocytes subset [41]. Retrospective analysis of PBMCs collected at post-mortem indicated that viral variants had evolved in each of the three animals[42], most notably in A611 and A613. The amplification of full-length env ORFs by limiting dilution PCR has been described previously[42]. In brief, $1 \times 10^{6}$ PBMCs were resuspended in $200 \mu$ phosphate buffered saline (PBS), and DNA was prepared using QIAamp DNA blood mini kit (QIAgen Ltd., Crawley, U.K.) as per manufacturer's instructions. The eluted DNAs were either used immediately for limiting-dilution PCR or stored at $-80^{\circ} \mathrm{C}$. The amplified products were cloned into either the GL8 $8_{\mathrm{MYA}}$ molecular clone or the eukaryotic expression vector VR1012 as previous[41]. A detailed analysis of mutation rates, recombination frequency and quasispecies diversity is described elsewhere[42]. In this study we focused on the quasispecies population from A613 as a preliminary analysis of a random selection of nucleic acid sequences obtained by direct sequencing of the products of the limiting-dilution PCR which indicated substantial amino acid sequence diversification. Nucleic acid sequences were ascertained by using a BigDye Terminator v1.1 cycle sequencing kit (Applied Biosystems, Warrington, United Kingdom) and analysis on an Applied Biosystems 3700 genetic analyser followed by chromatogram analysis using the Chromas v1.45 software package (Technelysium Pty. Ltd., Tewantin, Australia).

\section{Characterisation of env genes in vitro}

To assess whether the envs encoded functional products, they were cloned into the GL8 $8_{\text {MYA }}$ molecular clone as Mlu-I/Nde-I fragments as previous[41] and transfected into HEK-293T[43,44] cells using SuperFect activated dendrimer (QIAgen) as per manufacturer's instructions. Virus was recovered by passage of $0.45 \mu \mathrm{m}$-filtered supernatant onto MYA-1 cells[45], viral growth was then monitored visually for cytopathicity and confirmed by ELISA for p24. Simultaneously, Envs were subcloned as Sal-I/ Not-I fragments into pVR1012 (Vical Inc., San Diego, USA) and used to generated HIV(FIV)-luciferase pseudotypes. $5 \mu \mathrm{g}$ of each VR1012-env construct and $7.5 \mu \mathrm{g}$ of pNL4-3-Luc-E-R-[46] were co-transfected into HEK293T cells using SuperFect. The nomenclature "HIV(FIV)" denotes an FIV Env protein on an HIV parti- 
cle; reference pseudotypes bearing the GL8 and B2542 Envs have been described previously[27,28,37]. Culture supernatants were collected at 48 hours post-transfection, filtered at $0.45 \mu \mathrm{m}$ and frozen at $-80^{\circ} \mathrm{C}$ until required. Target cell lines were seeded at $5 \times 10^{4}$ cells per well of a CulturPlate ${ }^{\mathrm{m}}-96$ assay plate (Perkin Elmer, Life and Analytical Sciences, Beaconsfield, UK) and used immediately. The cells were then infected with $50 \mu \mathrm{l}$ of HIV(FIV) luciferase pseudotypes, cultured for 72 hours and then luciferase activity quantified by the addition of $50 \mu \mathrm{l}$ of Steadylite HTS $^{\text {mo }}$ (Perkin Elmer) luciferase substrate prior to measurement by single photon counting on a MicroBeta TriLux luminometer (Perkin Elmer).

\section{Exchange of variable loops in chimaeric GL8 Envs}

Variable loops were exchanged between envs in the vector GL8-414ABSN, a derivative of VR1012-GL8-414[47] which had been engineered to introduce ApaI, BssHII, SalI and NheI sites at nucleotides 1000, 1366, 1528 and 1848 respectively (facilitating the exchange of env fragments while reserving the integrity of the amino acid sequence). The BssHII site was introduced by PCRdirected mutagenesis using oligonucleotides 7644F 5'ACTGAAGCGCGCTTTAGGATT-3' and 7672R 5'CTACATCTAATCCTAAAGCGCGCTTC-3' while the NheI site was introduced with 8118F 5'-GCTATTCATGTTATGCTAGCTCTTG-3' and 8123R 5'-TTGCAAGAGCTAGCATAACATGA-3'. Fragments encompassing the V4 and V5 loops of variants B14, B19 and B28 were amplified using a high fidelity polymerase chain reaction and oligonucleotides incorporating flanking 5 ' BssHII and 3 ' NheI sites respectively (7644F and $8123 \mathrm{R})$. The products were then purified, digested and cloned into BssHII/ NheI digested GL8-414ABSN. The nucleic acid sequences of the chimaeric envs were confirmed as above and then the constructs used to prepare HIV(FIV) luciferase pseudotypes.

\section{Cells and viruses}

MYA-1 [45], CLL[27] and MCC[48] cells were cultured in RPMI 1640 medium; HEK-293T cells were maintained in Dulbecco's modification of Eagle's medium (DMEM). All media were supplemented with $10 \%$ foetal bovine serum (FBS), $2 \mathrm{mM}$ glutamine, $0.11 \mathrm{mg} / \mathrm{ml}$ sodium pyruvate 100 $\mathrm{IU} / \mathrm{ml}$ penicillin, $100 \mu \mathrm{g} / \mathrm{ml}$ streptomycin. The medium for MYA-1 cells was supplemented with conditioned medium from a murine cell line (L2.3) transfected with a human IL2 expression construct (kind gift of M. Hattori, University of Tokyo, Japan) at a final concentration equivalent to 100 $\mathrm{U} / \mathrm{ml}$ of recombinant human IL-2, and $50 \mu \mathrm{M} 2$-mercaptoethanol. All media and supplements were obtained from Invitrogen Life Technologies Ltd. (Paisley, UK). HEK-293T cells, and MCC and CLL cells bearing feline CD134 and its derivatives[27,49] were maintained in media supplemented with G418 (InVitrogen, Paisley, UK).

\section{Virus neutralising antibody (VNA) assays}

Plasmas were diluted 5-fold in MYA-1 culture medium, and then $25 \mu$ lof each dilution (in triplicate) were incubated with $25 \mu \mathrm{l}$ of HIV(FIV) luciferase pseudotype, incubated for one hour at $37^{\circ} \mathrm{C}$ and then added to $50 \mu \mathrm{l}(5 \times$ $10^{4}$ cells) of CLL-CD134[27] per well of a CulturPlate ${ }^{\text {m }}-96$ assay plate (Perkin Elmer). The cells were then cultured for 72 hours and luciferase activity quantified by the addition of $100 \mu \mathrm{l}$ of Steadylite HTS ${ }^{\text {mu }}$ (Perkin Elmer) luciferase substrate and measurement by single photon counting on a MicroBeta luminometer (Perkin Elmer). Percent neutralisation was calculated by comparing the mean luciferase counts at each plasma dilution with the mean luciferase counts for the no plasma control.

\section{Inhibition of viral entry}

$1 \times 10^{5}$ MYA- 1 or MCC-CD134 cells were incubated with either soluble Fc-TNC-CD134L[38] or Fc-CD134[38], or anti-CD134 (7D6)[39] in complete medium in triplicate wells of 96-well culture-treated luciferase assay plates (CulturPlate ${ }^{\mathrm{mm}}$ 96) for 30 minutes at $37^{\circ} \mathrm{C}$. In assessing whether pre-incubation with Fc-CD134 enhanced CD134-independent infection, virus was pre-incubated with Fc-CD134 for 30 minutes prior to plating on the target cell line. Viral pseudotypes were then added, and the plate was returned to the $37^{\circ} \mathrm{C}$ incubator. Cultures were maintained for 72 hours post-infection at which point $100 \mu \mathrm{l}$ of Steadylite HTS ${ }^{\mathrm{mw}}$ (Perkin Elmer) luciferase substrate were added and luminescence was measured by single photon counting on a MicroBeta luminometer (Perkin Elmer). Percent infection was calculated by comparing the mean $(\mathrm{n}=3)$ luciferase activity of each antagonist concentration against the mean $(n=3)$ luciferase activity of untreated cells (100\% infection).

\section{Results}

\section{Characterisation of the env quasispecies from A613}

The early phase of infection with the GL8 molecular clone has been described previously[41]; the virus established a high proviral load rapidly, and this was maintained throughout the duration of the study[41]. Viral variants cloned from A613 harboured mutations in regions of Env thought to be associated with tropism and/ or escape from neutralising antibody. It was striking that even after 322 weeks of infection, 7 species were isolated with identical amino acid sequences to the infecting strain GL8 (Fig. 1). Among the variants detected, hotspots for non-synonymous mutation were identified at the stem of the V1/V2 loop homologue (L265S, A268D, N269G and N269K) and the tip of the predicted V5 loop 


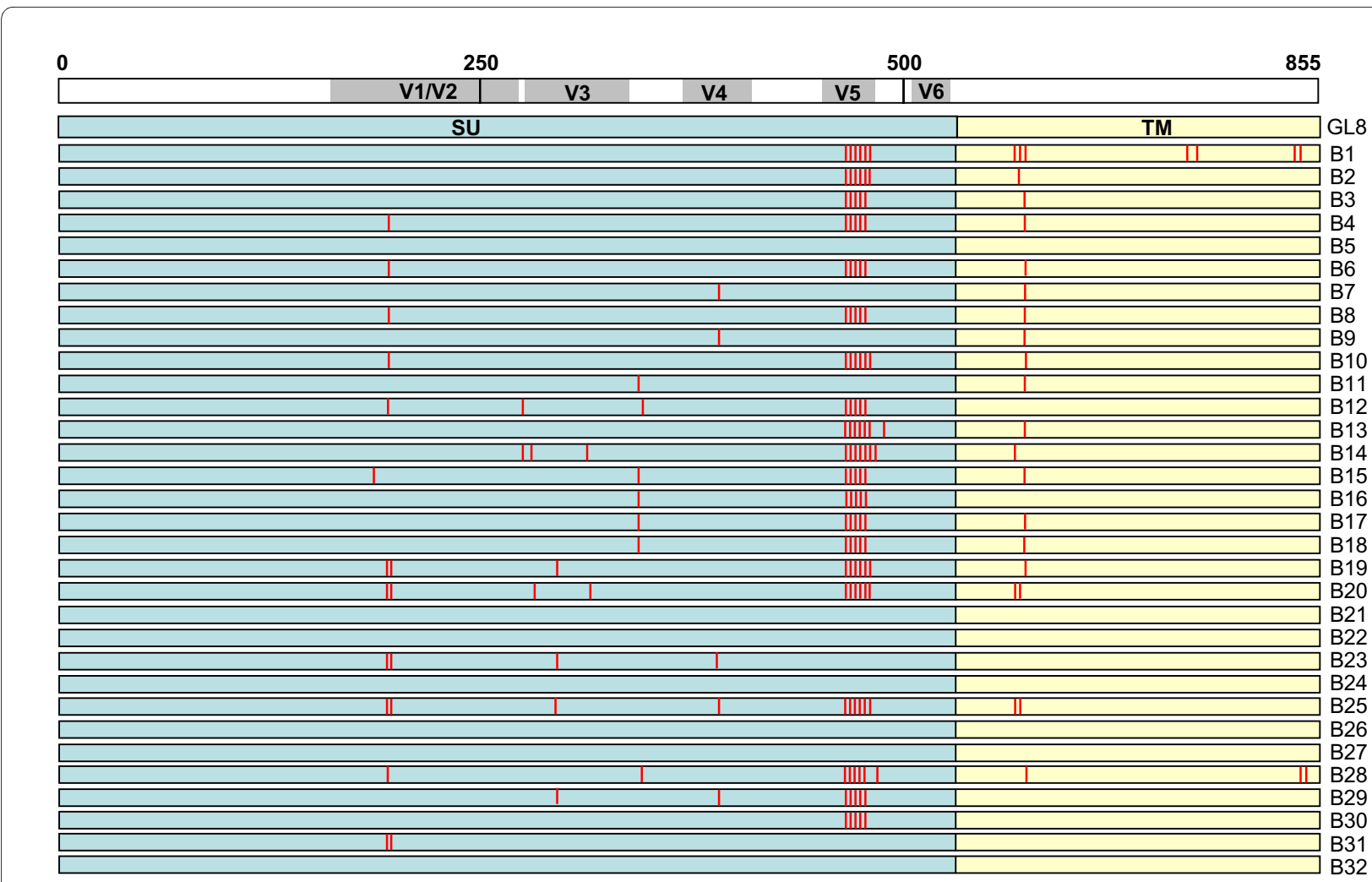

Figure 1 Locations of amino acid sequence mutations in the A613-derived Env clones. Mutations are marked by a red line in either SU (blue) or TM (yellow). Positions are shown relative to a linear representation of Env (SU and TM), amino acid numbering is indicated above.

in SU, and in TM (H648Q, T651A, V655M) (Fig. 2). The specific targeting of the region adjacent to and including the predicted N-linked glycosylation site at 269NNT271 was of particular interest as this region had been identified previously as a determinant of the Env-CD134 interaction[49]. The range of substitutions, insertions and deletions detected in the V5 loop region was remarkable and suggestive of a strong selective pressure on this region for evolution, potentially in evasion of the host immune response. Full length envs encoding intact open reading frames, and which generated replication-competent viruses following sub-cloning into the pGL8 MYA molecular clone and transfection into HEK-293T cells/ recovery into MYA-1 $\mathrm{T}$ cells, were subcloned into a eukaryotic expression vector and used to generate HIV(FIV) pseudotypes. The receptor usage and neutralisation sensitivity of the variants were then assessed in vitro. By comparing the distribution of amino acid sequence changes between the 32 clones, we identified 9 representative env clones that included the majority of the amino acid changes in Env that would allow us to distinguish the relative contributions of each variation from the parent sequence to escape from neutralisation and altered receptor usage.

\section{Receptor usage of Envs}

The GL8 strain of FIV requires determinants in both CRDs 1 and 2 of its primary receptor CD134 for infection; chimaeric receptors based on human CD134 and which express CRD1 only of feline CD134 (feCRD1 chimera) fail to support infection efficiently[27,37]. In contrast, strains such as B2542 and PPR use feCRD1 efficiently, suggesting a less stringent, or more flexible interaction with CD134. We have postulated that this "simple" interaction may evolve with disease progression, while the strains that dominate in early infection have a "complex" high affinity interaction[27,36,37]. The ability of the A613 variants to utilise native feline CD134 was compared with the feCRD1 chimera (Fig. 3). The prototypic strains with "complex" (GL8) and "simple" (B2542) interactions displayed high and low dependencies on CRD2 respectively (ratios of 117 and 5 respectively, derived by dividing the CPM on feCD134-expressing cells by the CPM on feCRD1-expressing cells). The variants isolated from the A613 quasispecies displayed a spectrum of receptor utilisations, from those similar to the GL8 parent (B23, B31 and B32, ratios of 223, 138 and 112) to those more similar to B2542 (B14, B28 and B30, ratios of 10,4 and 11). The amino acid sequences of clones B23, 31 


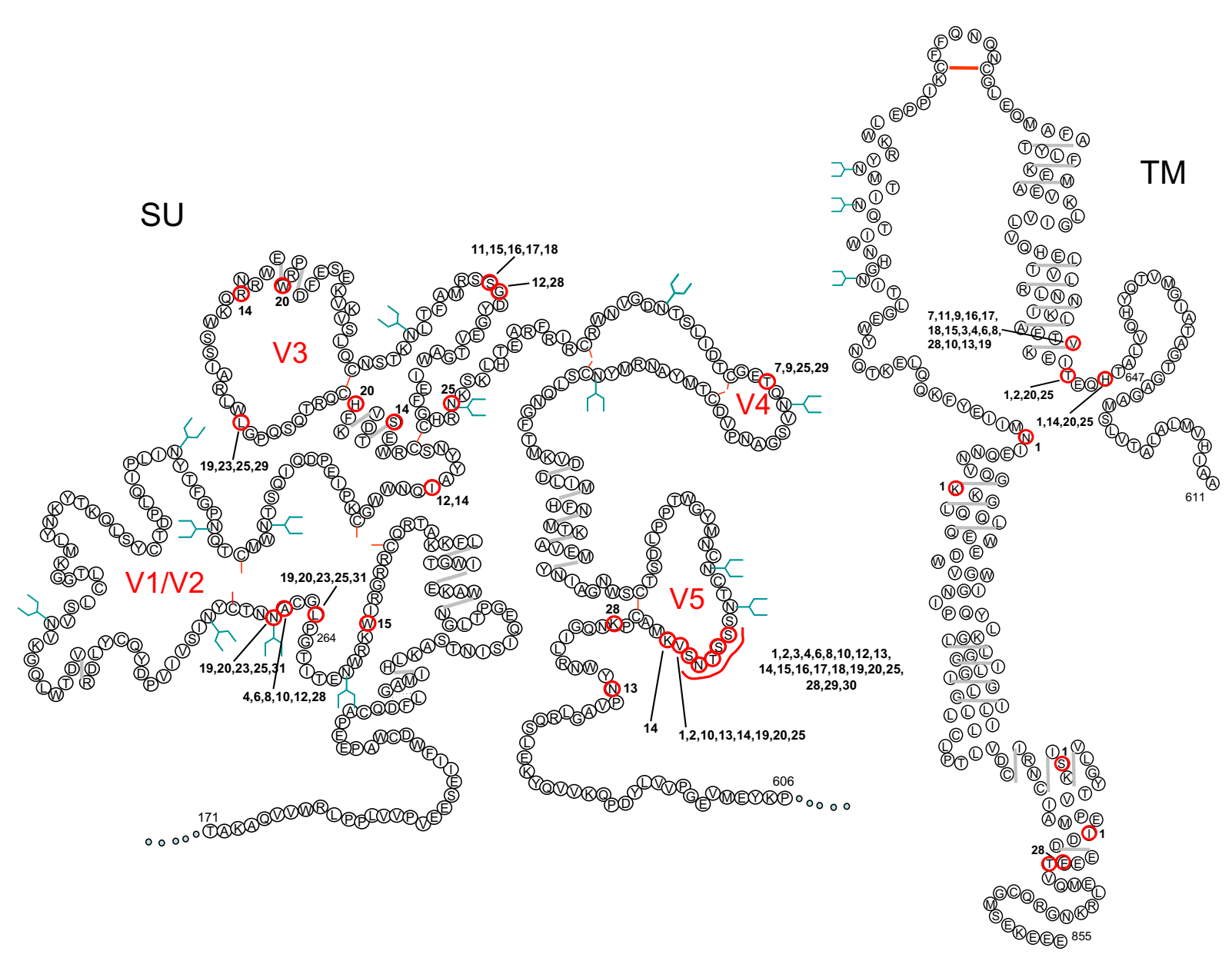

Figure 2 Schematic structural model of the FIV SU and TM proteins after Pancino et al[67], illustrating the locations of variations in the amino acid sequence of the $\mathbf{A} \mathbf{6 1 3}$ variants. Mutated amino acids are circled (red) with individual clone numbers indicated. Also shown are potential sites for N-linked glycosylation (blue "Y"), di-sulphide bond formation (red line between cysteines) and predicted a-helice formation (grey line).

and 32 were identical across V5. The emergence of variants such as B28 that are able to use the feCRD1 chimera is consistent with in vivo evolution towards a "simple" mode of interaction.

Six of the viral variants with distinct Envs were analysed further for sensitivity to antagonists of the virusreceptor interaction (Fig. 4). Variant B32 was identical to the parent strain GL8 and therefore served as the reference strain. If the nature of the virus-receptor interaction had evolved in vivo, it is likely that this would be reflected in altered sensitivity to antagonism by anti-CD134 antibody (7D6), soluble CD134 (sFc-CD134) or soluble CD134L (sFc-TNC-CD134L). The six variants displayed a spectrum of sensitivities to inhibition by 7D6 (Fig. 4A); B31 and B32 were relatively resistant to inhibition by 7D6, a maximal reduction of $\sim 40 \%$ inhibition at $2 \mu \mathrm{g} / \mathrm{ml}$ while at high concentrations the inhibitory effect disappeared (as noted previously for GL8[39]). In stark con- trast, infection with variants B28 and B14 was reduced by $70 \%(\mathrm{P}=0.014)$ and $90 \%(\mathrm{P}=0.003)$ respectively at 0.4 $\mu \mathrm{g} / \mathrm{ml}$ and blocked completely $(>99 \%)$ at all concentrations of $2.0 \mu \mathrm{g} / \mathrm{ml}$ or greater $(\mathrm{P}=0.0004$ at $50 \mu \mathrm{g} / \mathrm{ml})$. Thus the mutations acquired by B28 and B14 in vivo had significantly enhanced sensitivity to antagonism by 7D6. We next asked whether the viruses differed in their sensitivities to antagonism by soluble CD134 (sFc-CD134) (Fig. 4B). Infection with B19, B30, B31 and B32 was blocked with a similar efficiency, a $50-60 \%$ reduction in infectivity being achieved at $2 \mu \mathrm{g} / \mathrm{ml} \mathrm{sFc-CD134}$ and $>95 \%$ at the maximum concentration tested $(50 \mu \mathrm{g} / \mathrm{ml})$. These observations are in marked contrast to pseudotypes bearing the Envs of variants B14 ( $\mathrm{P}=0.0003$ at $2 \mu \mathrm{g}$ / $\mathrm{ml})$ and B28 $(\mathrm{P}=0.0002$ at $2 \mu \mathrm{g} / \mathrm{ml})$ which were significantly more resistant to antagonism by soluble CD134 (Fig. 4B.), indicating an alteration in the nature of the virus-receptor interaction following evolution in vivo. It 


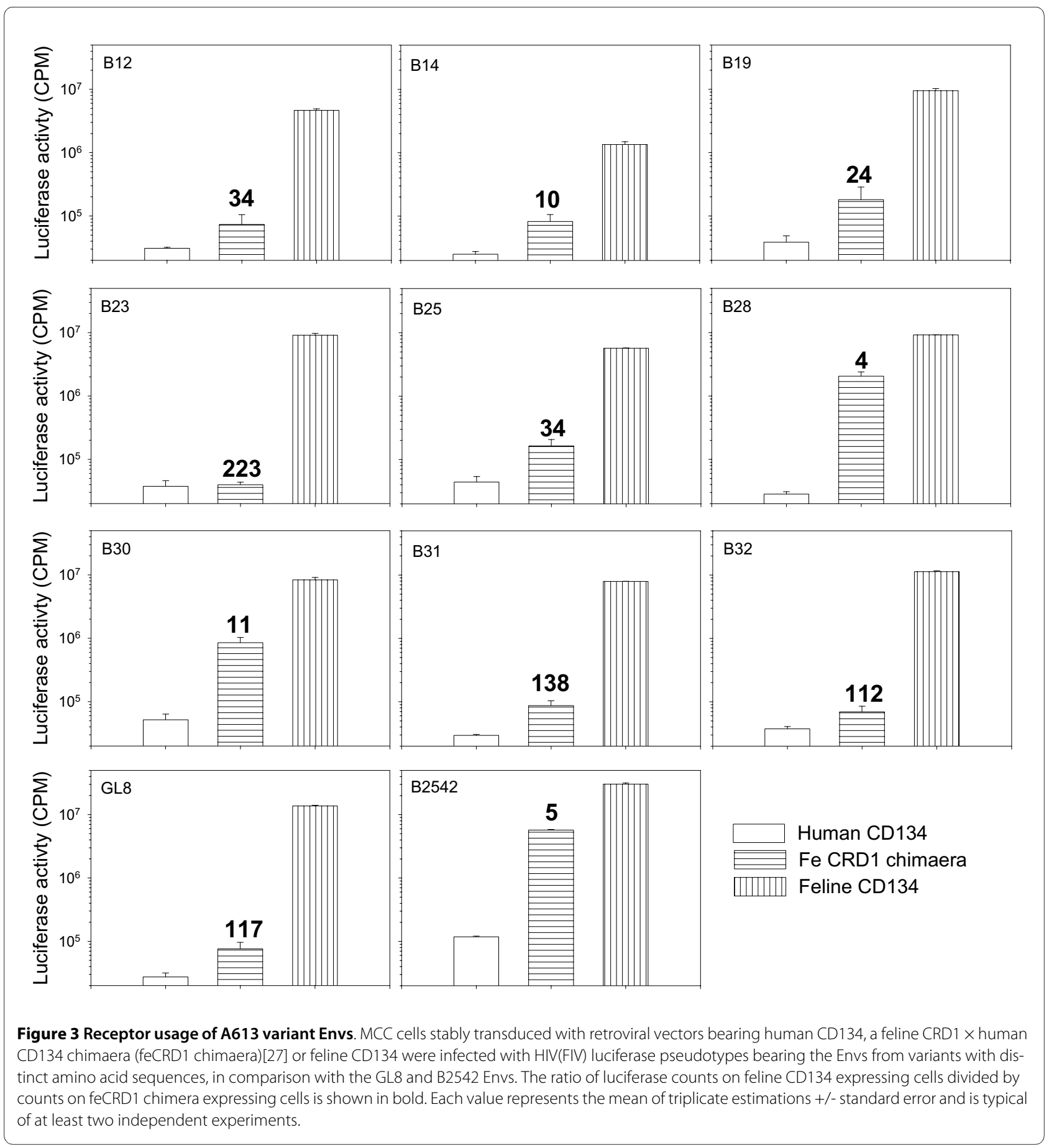

is noteworthy that the two variants that were most sensitive to inhibition by 7D6 (B14 and B28) were most resistant to antagonism by sFc-CD134.

Previous studies demonstrated that infection with primary isolates such as GL8 and CPG41 was relatively resistant to antagonism by soluble CD134L (sFc-TNCCD134L) while infection with strains such as B2542 and PPR was sensitive to modulation[38,39]. sFc-TNCCD134L had a modest inhibitory effect on infection with the six viral variants however most sensitive to inhibition were B14 and B28 (Fig. 4C, significant reduction at $10 \mu \mathrm{g}$ / $\mathrm{ml}, \mathrm{P}=0.004$ and 0.007 respectively), consistent with the enhanced sensitivity of these two strains to anti-CD134 and reduced sensitivity to soluble CD134.

Previous studies have suggested that pre-incubation of FIV with soluble Fc-CD134 fusion proteins may facilitate infection of CXCR4-expressing (CD134-negative) cells[50,51], the studies indicating that engagement of 

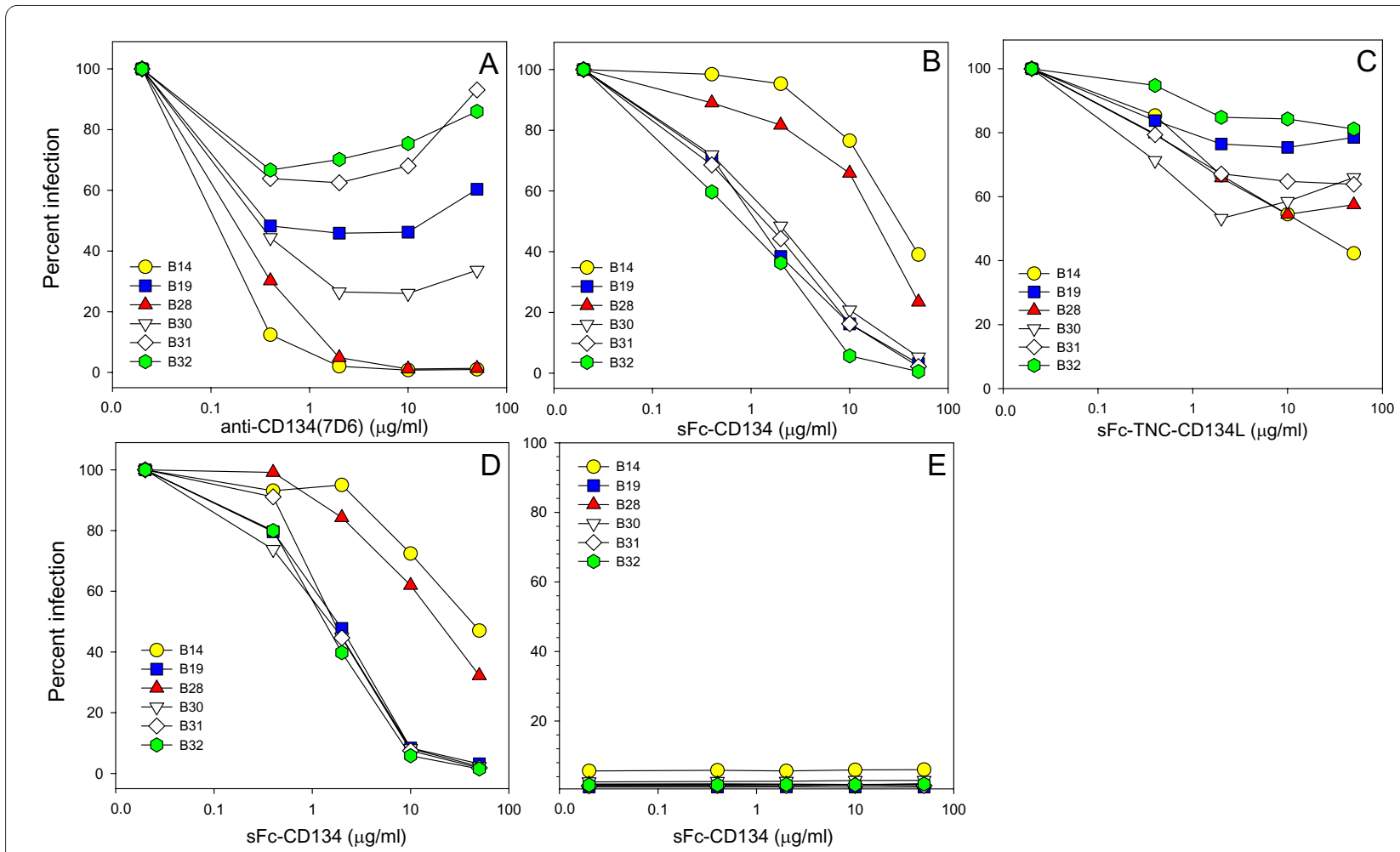

Figure 4 Sensitivity of $A 613$ Env variants with distinct receptor usages to antagonists of the virus-receptor interaction. HIV(FIV) luciferase pseudotypes bearing the B14, B19, B28, B30, B31 and B32 Envs were examined for sensitivity to antagonism by anti-CD134 (A), SFC-CD134 (B, D, E) or sFc-TNC-CD134L (C). Infections were performed on MYA-1 cells (A-C), MCC-CD134 (D) or MCC control (E). (E) Pre-incubation with sFc-CD134 did not facilitate CD134-independent infection of MCC control cells. Each point represents the mean of triplicate estimations and is expressed as percent infection relative to no antagonist control. Each graph is typical of at least two independent experiments.

soluble CD134 triggers a conformational change in the FIV Env that exposes the CXCR4 binding site[50,51]. Given the low sensitivity of variants B14 and B28 to antagonism by sFc-CD134 on IL2-dependent (MYA-1) T cells, we postulated that these variants may partially escape antagonism by sFc-CD134 by utilising CXCR4 for infection. To examine this hypothesis, MCC cells stably transduced with a retroviral vector bearing CD134 (Fig. $4 \mathrm{D})$ or vector only (Fig. 4E) were infected with viral pseudotypes following pre-treatment with sFc-CD134. As observed with IL2-dependent $\mathrm{T}$ cells (Fig. 4B), sFcCD134 blocked infection of MCC-CD134 efficiently with variants B19, B30, B31 and B32 while variants B14 and B28 proved more resistant. The sensitivity of the variants to inhibition was very similar on both MYA-1 and MCCCD134 substrates; given that MCC-CD134 express 100fold more surface CD134 than MYA-1 cells[38] the data suggest that the Env-sFcCD134 interaction itself determines the degree of inhibition and that within the range examined, the level of surface CD134 expression on the target cell does not influence the outcome. When the sFcCD134 pre-treated pseudotypes were plated onto control MCC cells (Fig. 4E), cells that are CD134-negative and CXCR4-positive[49], we observed no evidence of enhanced infection by adding increasing concentrations of sFc-CD134 (values are expressed as percent infection of control MCC cells compared with MCC-CD134). The data suggest that pre-incubation of these viruses with sFc-CD134 does not trigger exposure of the CXCR4binding site and mediate CD134-independent infection. Thus the differential sensitivities of variants B14 and B28, and variants B19, B30, B31 and B32, to inhibition by sFcCD134 and sFc-TNC-CD134L more likely reflects an intrinsic shift in the nature of the Env-CD134 interaction with evolution in vivo.

\section{Sensitivity to neutralising antibody}

Pressure from the adaptive immune response may drive the emergence of variants of HIV-1 with novel cell tropisms[52,53] while the growth of viruses in cell culture in vitro can select for variants with distinct neutralisation properties[54]. Given that variants had evolved in vivo with distinct modes of interaction with CD134, we next asked whether evasion of the humoral immune response may have provided the driving force for Env evolution. The sensitivity of nine unique viral variants to neutralisation by plasma collected post-mortem was assessed in vitro in comparison with the parent GL8 clone. GL8 and 


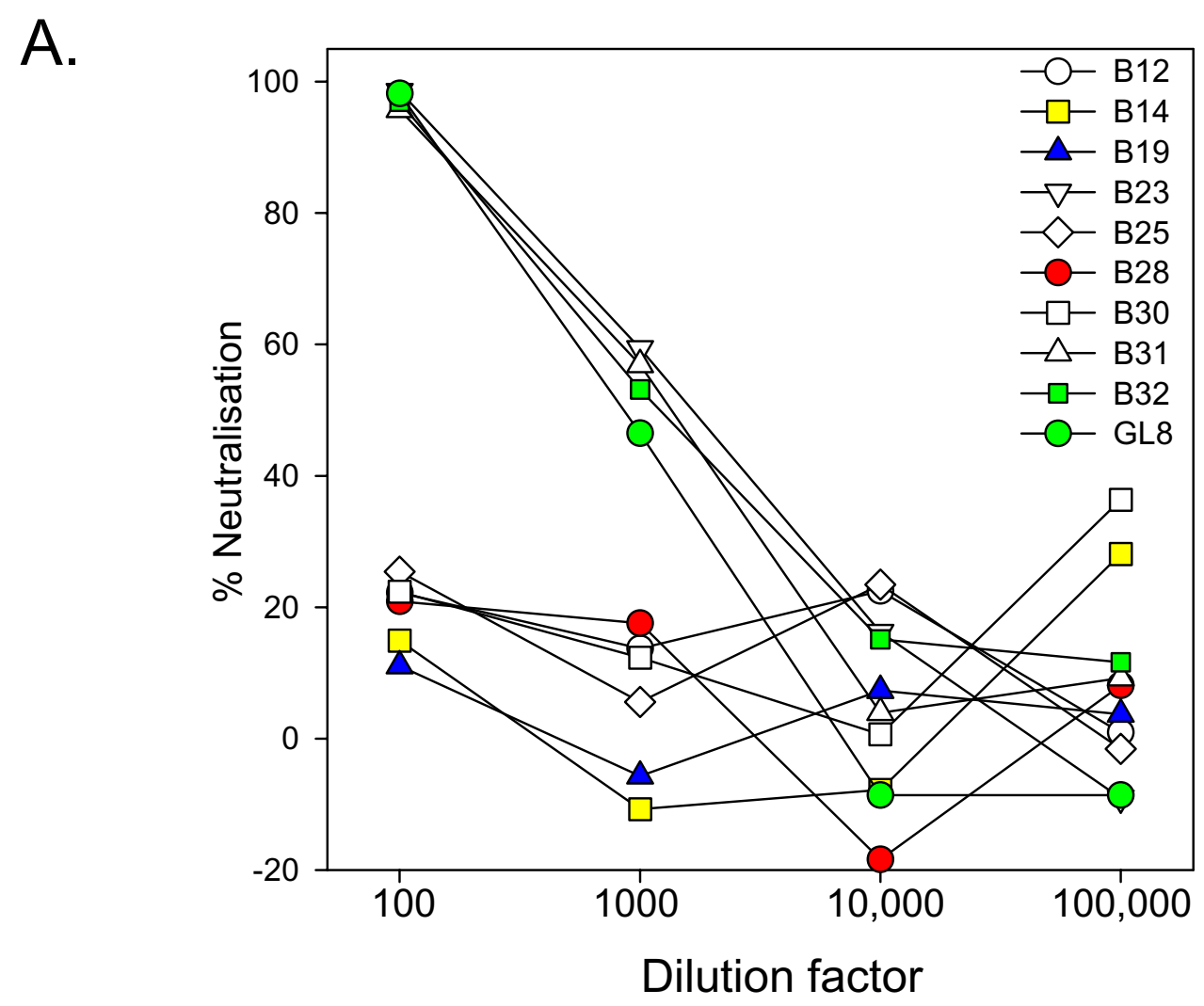

B.

\begin{tabular}{|c|c|c|c|c|c|c|c|c|c|c|c|c|c|c|c|c|c|c|c|c|c|c|c|c|}
\hline & & & & & & & & & & & & & & & & & & & & & & & & V \\
\hline C & $\mathbb{N}$ & C & $\mathrm{T}$ & $\mathbb{N}$ & $S$ & $S$ & $S$ & $\mathrm{~T}$ & $\mathbb{N}$ & & Q & $N$ & $S$ & $S$ & $S$ & $\mathrm{~T}$ & $N$ & $S$ & $\mathrm{~V}$ & & & A & C & B12 \\
\hline C & $N$ & $\mathrm{C}$ & $T$ & $N$ & 5 & 5 & 5 & $\mathrm{~T}$ & $N$ & - & - & & 5 & $S$ & $S$ & $T$ & $N$ & $S$ & $G$ & & (1) & $\mathrm{A}$ & $\mathrm{C}$ & 314 \\
\hline C & $N$ & $\mathrm{C}$ & $T$ & $N$ & - & - & - & - & - & - & - & - & - & $S$ & $S$ & $T$ & $N$ & $S$ & $G$ & & 4 & A & $\mathrm{C}$ & 319 \\
\hline C & $N$ & C & $T$ & $N$ & $S$ & - & - & - & - & - & - & 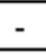 & - & $S$ & $S$ & $T$ & & $\mathrm{~S}$ & & & & $\mathrm{~A}$ & C & \\
\hline $\mathrm{C}$ & $N$ & C & $T$ & $N$ & $S$ & 5 & - & - & - & - & - & - & 5 & $\mathrm{~T}$ & $S$ & $T$ & $N$ & $S$ & $\mathrm{G}$ & & & A & C & 325 \\
\hline C & $\mathrm{N}$ & C & $T$ & $N$ & $S$ & $S$ & 5 & $T$ & $N$ & & $\bar{Q}$ & $\mathbf{N}$ & $S$ & $S$ & $S$ & $T$ & & $S$ & & & & A & C & \\
\hline C & $N$ & $\mathrm{C}$ & $T$ & $N$ & $S$ & 5 & 5 & $\mathrm{~T}$ & $N$ & - & - & & & - & $S$ & $T$ & & $S$ & $V$ & & & $\mathrm{~A}$ & C & 330 \\
\hline $\mathrm{C}$ & $N$ & $\mathrm{C}$ & $T$ & $N$ & $S$ & - & - & - & - & - & - & - & - & 5 & $S$ & $T$ & $N$ & 5 & $V$ & & & $\mathrm{~A}$ & $\mathrm{C}$ & 331 \\
\hline C & $N$ & C & $T$ & $N$ & $S$ & - & - & - & - & - & - & - & - & $S$ & $S$ & $T$ & & 5 & $V$ & & & $\mathrm{~A}$ & $\mathrm{C}$ & 332 \\
\hline C & $\mathbb{N}$ & C & $\mathrm{T}$ & $\mathbb{N}$ & 5 & - & - & - & 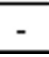 & - & - & & & 5 & 5 & $\bar{T}$ & $N$ & 5 & & & & $\mathrm{~A}$ & & jL8 \\
\hline
\end{tabular}

Figure 5 A) Sensitivity of Env variants to neutralisation by homologous plasma from A613. HIV(FIV) luciferase pseudotypes bearing the B12, B14, B19, B23, B25, B28, B30, B31, B32 and GL8 Envs were incubated with 1:100, 1:1000, 1:10,000 or 1:100,000 dilutions of A613 plasma and plated onto CLL-CD134 cells[27]. Luciferase activity was measured at 72 hours post-infection. Each point represents the mean of triplicate estimations and is expressed as percent neutralisation relative to the no plasma control. Each graph is typical of at least two independent experiments. B) Neutralising activity correlates with variability in the $\mathbf{V} \mathbf{5}$ region of Env. Amino acid residues are coloured according to chemical type: basic (dark blue), acidic (red), hydrophobic (white), hydroxyl (salmon pink), sulphur-containing (yellow) or amido (lavender blue). Presence or absence of neutralisation is summarised alongside by a green tick or red cross respectively.

the closely related clones $\mathrm{B} 23,31$ and 32 were neutralised effectively by the P.M. plasma (Fig. 5A). In contrast, clones B12, B14, B19, B25, B28 and B30 resisted neutralisation by the plasma. The amino acid sequences of the nine variants were compared with the GL8 clone. Although no single amino acid substitution correlated with resistance to neutralising antibody, resistance did correlate with the acquisition of mutations in V5 per se. 
While the V5 loops of B23, 31 and 32 were identical to GL8, those of B12, B14, B19, B25, B28 and B30 bore amino acid insertions, substitutions or deletions (Fig. 5B). The data suggest that the V5 region may be a dominant target for neutralising antibody and that antibodies targeting this region may drive immune escape in FIV infection.

\section{Exchange of the V5 loop confers resistance to neutralisation and modulates the virus-receptor interaction}

The data suggest that the viral variants derived in vivo escaped neutralising antibody by the acquisition of mutations in the V5 loop region. We therefore generated chimaeric envs in which a fragment encompassing the V4 and V5 loops of the parent 414 strain was exchanged with the equivalent regions (nts. 1366-1848) of the variants B14, B19 and B28; HIV(FIV) pseudotypes were prepared and the sensitivities of the chimaeric Envs to neutralising antibodies were examined. The mutated GL8 clone ABSN retained the neutralisation sensitivity of the parent clone to the A613 plasma, confirming the integrity of the amino acid sequence post-mutagenesis (Fig. 6). In contrast, substitution of the V4-V5 domain of ABSN with the corre-

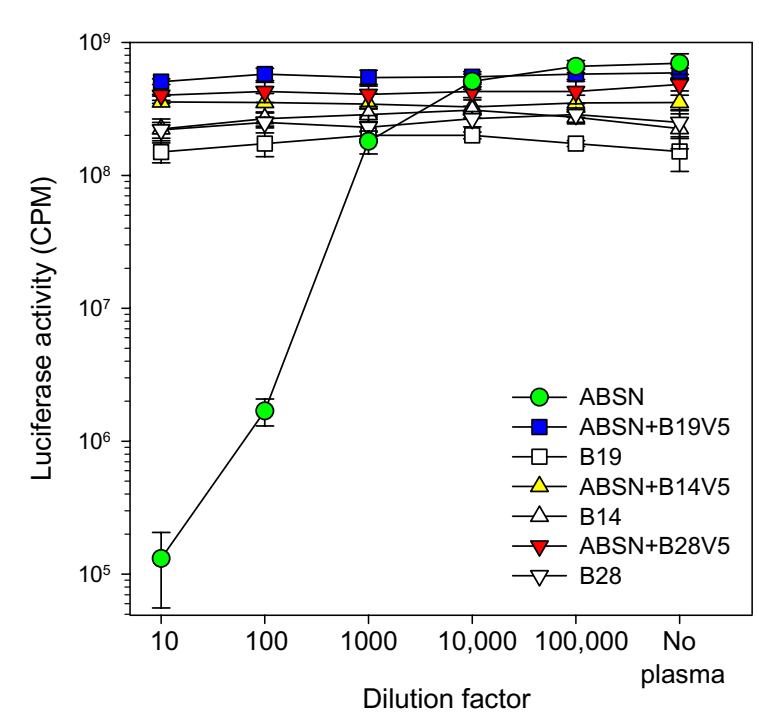

Figure 6 Conferral of resistance to neutralisation by homologous plasma following V5 loop exchange. GL8 Env incorporating noncoding mutations that introduced restriction enzyme sites facilitating V5 loop exchange (GL8 "ABSN") was compared with three chimaeric Envs in which the V5s of B14, 19 and 28 had been introduced, or the parent B14, B19 and B28 Envs. HIV(FIV) luciferase pseudotypes bearing each Env were incubated with 1:10, 1:100, 1:1000, 1:10,000 or 1:100,000 dilutions of A613 plasma and plated onto CLL-CD134 cells. The chimaeric Envs bearing the $V 5$ s of B14, B19 and B28 recapitulated the neutralisation-resistant phenotype of the parent Envs. Each point represents the mean (+/-SE) of three replicates and is typical of at least two independent experiments. sponding domain of variants B14, B19 or B28 rendered the virus resistant to neutralisation (Fig. 6). Given that the only variation in the V4-V5 region between variants B14, B19 and B28 and the parent clone was the V5 loop itself, the data are consistent with the dominant neutralising activity of the PM plasma from A613 targeting V5.

Following exchange of the V4-V5 region of ABSN with that of the B14, B19 and B28, we assessed the sensitivity of the chimaeric Env-bearing HIV(FIV) pseudotypes to antagonists of the virus-receptor interaction (Fig. 7). The reference GL8 Env (ABSN) conferred low sensitivity to anti-CD134 (Fig. 7A, 50.9\% infection at $2 \mu \mathrm{g} / \mathrm{ml}$ ) and high sensitivity to sCD134 (Fig. 7B, 18.4\% infection at $2 \mu \mathrm{g} / \mathrm{ml}$ ) while in contrast, the B14 Env displayed the reverse phenotype, an enhanced sensitivity to anti-CD134 (Fig. 7A, $19.5 \%$ infection at $2 \mu \mathrm{g} / \mathrm{ml}$ ) and reduced sensitivity to sCD134 (Fig. 7B, $78.2 \%$ infection at $2 \mu \mathrm{g} / \mathrm{ml}$ ). In comparison to the GL8(ABSN) and B14 reference Envs, the ABSN-B14-V5 chimera acquired the phenotype of the B14 Env, with high sensitivity to anti-CD134 (Fig. 7A, $6.2 \%$ infection at $10 \mu \mathrm{g} / \mathrm{ml}$, significant increase $P=0.002$ ) and low sensitivity to sCD134 (Fig. 7B, 65.1\% infection at $10 \mu \mathrm{g} / \mathrm{ml}$, significant reduction $\mathrm{P}=0.002)$. B14 was comparatively more sensitive to inhibition by sCD134L (Fig. 7C) however exchange of V5 was insufficient to recapitulate this phenotype. The V5 loops of B19 and B28 had more marginal effects; B28 V5 was similar to that of B14 in that it enhanced sensitivity to anti-CD134 and reduced sensitivity sCD134; however, the effect was less marked than that observed with the B14-V5 (as had been observed with the B28 Env itself earlier (Fig. 4)), suggesting that determinants out with V5 may contribute to the phenotype of the B28 Env. The sensitivity of the B19 V5 chimera to antagonists of the virus-receptor interaction did not differ significantly from the GL8 ABSN parent Env. The data suggest that in the correct context, alterations in the V5 loop that confer resistance to virus neutralisation may modulate substantially the virus-receptor interaction.

\section{Discussion}

In this study, we have demonstrated the evolution of receptor usage following infection with a homogeneous preparation of a pathogenic molecular clone of FIV. A shift in cell tropism with time post-infection has been described previously for FIV $[55,56]$ and yet the molecular basis for such a shift has yet to be established. As all strains of FIV examined to date use CXCR4 as the coreceptor for infection, an R5 to $\times 4$ shift analogous to that observed in HIV infection cannot be invoked. Indeed, while $\times 4$ variants emerge in approximately $50 \%$ of HIVinfected individuals and their detection is often associated with disease progression [21-23], progression to AIDS may also occur in the absence of $\times 4$ variants sug- 


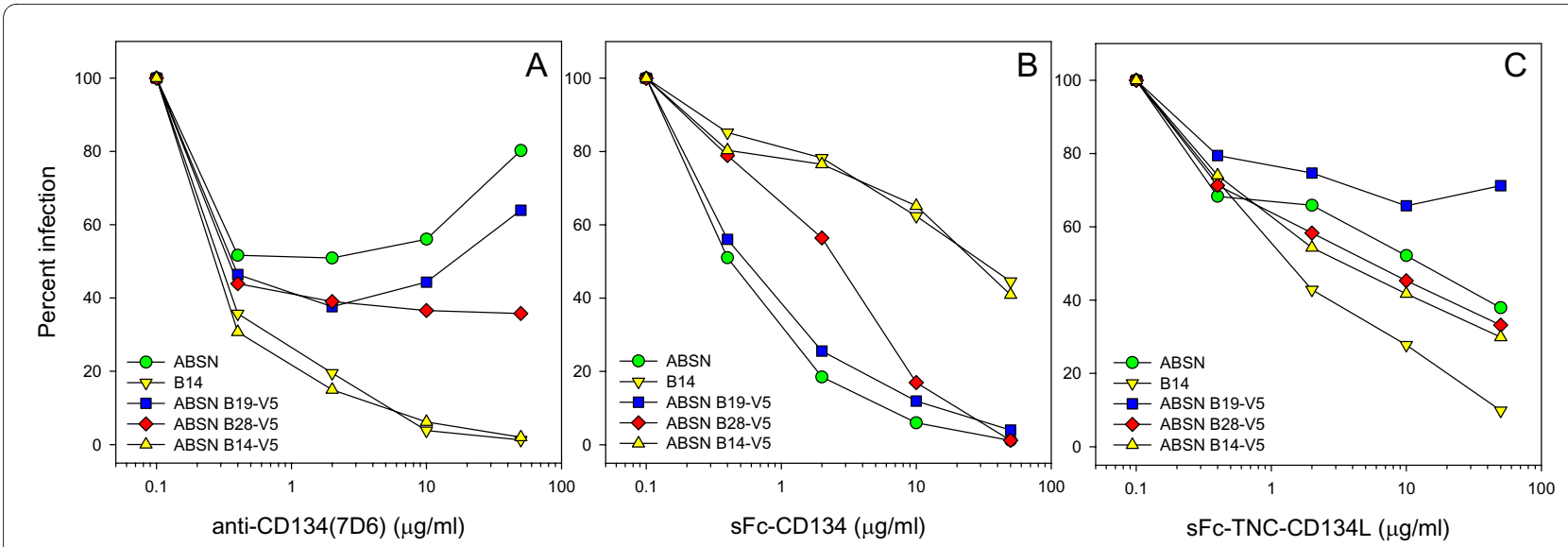

Figure 7 Effect of V5 loop exchange upon sensitivity to antagonists of the virus-receptor interaction. HIV(FIV) luciferase pseudotypes bearing the GL8 (ABSN) or B14 Envs, or ABSN+V5 loops of B14, 19 and 28 were examined for sensitivity to antagonism by anti-CD134 (A), sFc-CD134 (B) or sFCTNC-CD134L (C). Infections were performed on MYA-1 cells. Each point represents the mean of triplicate estimations and is expressed as percent infection relative to no antagonist control. Each graph is typical of at least two independent experiments.

gesting that there is not a causal link between the presence of $\times 4$ variants and the development of AIDS. Further, the expanded cell tropism of $\times 4$ variants may come at a cost to the virus in that $\times 4$ variants have been observed to be targeted more readily by neutralising antibodies and may be kept in check by the humoral immune response in early infection. Given that determinants of cell tropism and virus neutralisation may be shared, pressure for escape from neutralising antibodies may drive alterations in receptor usage and cell tropism[52,53]. In this study, we present the first evidence for the evolution of the FIV-CD134 interaction in vivo. The animal examined in this study was infected with a homogeneous stock of a molecularly-cloned virus (GL8), a virus known to induce a decline in CD4+ lymphocytes, achieve a high viral load and to have a "complex" interaction with CD134. At post-mortem approximately six years postinfection, variants were isolated from peripheral blood of the cat that were resistant to neutralisation by homologous plasma and which had an altered interaction with CD134. It is notable that even six years post-infection we were still able to amplify envs that were identical to the challenge virus. The diversity of FIV is likely to result from a combination of the infidelity of reverse transcriptase, inter-variant recombination and the cytidine deaminase activities of APOBECs, with additional selective pressure from the host immune response and the level of receptor and co-receptor expression upon a target cell population. While the homogeneity of the challenge virus may have reduced the complexity of the quasispecies observed at post-mortem, we were afforded a unique opportunity to observe the shift in receptor usage in vivo that we had predicted in vitro. Why should FIV alter the way it interacts with CD134? Our studies with antago- nists of the CD134 interaction suggest that the affinity of the Env for the primary receptor CD134 may alter as a consequence of escape from neutralising antibody. Surprisingly, we have uncovered mutations in the highly variable V5 loop of FIV Env that contribute significantly to the virus receptor interaction.

Sequential isolates of HIV and SIV have demonstrated the evolution of co-receptor usage in vivo with disease progression [24,57-61] as predicted by the frequent isolation of CXCR4 variants in symptomatic individuals[21]. Less well-studied are the alterations in the interaction between lentiviruses and their primary receptor. Intrapatient alterations in the V1V2 and V3 regions of HIV Env can modulate not only co-receptor usage but also binding to the primary receptor CD4[62]. Given that FIV uses a single co-receptor (CXCR4) for infection, the observation that the interaction between the virus and its primary receptor evolves in vivo may provide a mechanism whereby the virus can expand into additional cellular compartments.

Variants B14 and B28 were able to use CRD1 of feline CD134, displayed enhanced sensitivity to antagonism by anti-CD134 antibody or soluble Fc-TNC-CD134L and were more resistant to inhibition by sFc-CD134, suggesting that the evolution of the virus-receptor interaction may not simply be a modulation of binding affinity, rather it could represent a shift in the way the Env and receptor interact. The two modes of interaction may be considered as either "complex" (requiring CRD1 and CRD2) or "simple" (requiring CRD1 only)[36]. It is possible that the "complex" interaction involves trimeric Env engaging with trimeric CD134 and is of high affinity while the "minimal" interaction results from Env binding to either trimeric or monomeric CD134. Thus the latter pheno- 
type of virus would be more sensitive to inhibition by monomeric/dimeric sFc-CD134. As receptor multimerisation may be promoted by ligand association, or by antiCD134 antibody treatment, the viruses engaging in a complex interaction may selectively target cells exposed in vivo to soluble CD134L (for example helper $\mathrm{T}$ cells in proximity to $\mathrm{CD} 134 \mathrm{~L}$-expressing antigen presenting cells). In contrast, viruses interacting through CRD1 alone may be suppressed in vivo by endogenously produced soluble CD134L.

Many of the variants isolated at post-mortem were resistant to neutralisation by homologous plasma and each resistant variant harboured mutations in the V5 loop of Env. Exchange of V5 loops between the parent virus and the late variants confirmed that neutralisation resistance was afforded by the V5 mutations. A comparison of neutralization sensitivities on three different cellular substrates (MYA-1, MCC-CD134 and CLL-CD134) gave similar findings (not shown) suggesting that the targeting of V5 was not a vagary of the assay system employed to measure VNA. The recognition of a linear peptide from variant B28 by the post-mortem plasma from A613 (not shown) confirms that the region is immunogenic, however, as we were unable to detect binding of antibodies within the A613 plasma to linear peptides derived from the neutralizable parent clone, the epitope targeted by the VNA is likely to consist of conformational epitopes encompassing V5. Previous studies have emphasised the importance of epitopes within V4 and V5 as targets for neutralising antibody and the way in which a single epitope may dominate within polyclonal sera [6366]. Understanding the process of immune evasion may yield valuable insights into the design and optimisation of candidate vaccine immunogens that induce a protective immune response.

\section{Competing interests}

The authors declare that they have no competing interests.

\section{Authors' contributions}

EM, MK and NL performed the DNA manipulations, cell culture, viral pseudotype preparation and entry assays. AS assisted with the virus neutralisation assays. $\mathrm{MH}$ and $\mathrm{BW}$ designed the experiments and wrote the manuscript. All authors read and approved the final manuscript

\section{Acknowledgements}

This work was supported by funding from the Biotechnology and Biological Sciences Research Council and The Wellcome Trust to B.J.W and M.J.H.

\section{Author Details}

Retrovirus Research Laboratory, Institute of Comparative Medicine, Faculty of Veterinary Medicine, University of Glasgow, Bearsden Road, Glasgow G61 1QH, UK

Received: 4 March 2010 Accepted: 26 April 2010

Published: 26 April 2010
References

1. Torten M, Franchini M, Barlough JE, George JW, Mozes E, Lutz H, Pedersen NC: Progressive immune dysfunction in cats experimentally infected with feline immunodeficiency virus. J Virol 1991, 65:2225-2230.

2. Ackley CD, Yamamoto JK, Levy N, Pedersen NC, Cooper MD: Immunologic abnormalities in pathogen-free cats experimentally infected with feline immunodeficiency virus. J Virol 1990, 64:5652-5655.

3. Yamamoto JK, Hansen H, Ho EW, Morishita TY, Okuda T, Saura TR, Nakamura RM, Pedersen NC: Epidemiologic and clinical aspects of FIV infection in cats from the continental U.S. and Canada and possible mode of transmission. J Am Vet Med Assoc 1989, 194:213-220.

4. Sparger EE, Luciw PA, Elder JH, Yamamoto JK, Lowenstine LJ, Pedersen NC: Feline immunodeficiency virus is a lentivirus associated with an AIDSlike disease in cats. AIDS 1989, 3:S43-S49.

5. Pedersen NC, Ho EW, Brown ML, Yamamoto JK: Isolation of a Tlymphotropic virus from domestic cats with an immunodeficiency syndrome. Science 1987, 235:790-793.

6. Hosie MJ, Robertson C, Jarrett O: Prevalence of feline leukaemia virus and antibodies to feline immunodeficiency virus in cats in the United Kingdom. Vet Rec 1989, 125:293-297.

7. Pedersen NC: The feline immunodeficiency virus. In The Retroviridae Edited by: Levy JA. New York: Plenum Press; 1993:181-228.

8. Callanan JJ, Thompson H, Toth SR, O'Neil B, Lawrence CE, Willett BJ, Jarrett $O$ : Clinical and pathological findings in feline immunodeficiency virus experimental infection. Vet Immunol Immunopathol 1992, 35:3-13.

9. Callanan JJ, Jones BA, Irvine J, Willett BJ, McCandlish IAP, Jarrett O: Histological classification and immunophenotype of lymphosarcomas in cats with naturally and experimentally acquired feline immunodeficiency virus infections. Vet Pathol 1996, 33:264-272.

10. Murray JK, Browne WJ, Roberts MA, Whitmarsh A, Gruffydd-Jones TJ: Number and ownership profiles of cats and dogs in the UK. Vet Rec 2010, 166:163-168.

11. Willett BJ, Flynn JN, Hosie MJ: FIV infection of the domestic cat: an animal model for AIDS. Immunol Today 1997, 18:182-189.

12. Bendinelli M, Pistello M, Lombardi S, Poli A, Garzelli C, Matteucci D, Ceccherini-Nelli L, Malvaldi G, Tozzini F: Feline immunodeficiency virus: an interesting model for AIDS studies and an important cat pathogen. Clin Microbiol Rev 1995, 8:87-112.

13. Maddon PJ, Dalgleish AG, McDougal JS, Clapham PR, Weiss RA, Axel R: The T4 gene encodes the AIDS virus receptor and is expressed in the immune system and the brain. Cell 1986, 47:333-348.

14. Dalgleish AG, Beverley PCL, Clapham PR, Crawford DH, Greaves MF, Weiss RA: The CD4 (T4) antigen is an essential component of the receptor for the AIDS retrovirus. Nature 1984, 312:763-767.

15. Klatzmann D, Champagne E, Chamaret S, Guetard D, Hercend T, Gluckmann JC, Montagnier L: T-lymphocyte T4 molecule behaves as the receptor for human retrovirus LAV. Nature 1984, 312:767-768.

16. Feng Y, Broder CC, Kennedy PE, Berger EA: HIV-1 entry co-factor: functional CDNA cloning of a seven-transmembrane, $G$ proteincoupled receptor. Science 1996, 272:872-877.

17. Alkhatib G, Combadiere C, Broder CC, Feng Y, Kennedy PE, Murphy PM, Berger EA: CC CKR5: A RANTES, MIP-1a, MIP-1b receptor as a fusion cofactor for macrophage-tropic HIV-1. Science 1996, 272:1955-1958.

18. Dragic T, Litwin T, Allaway GP, Martin SR, Huang Y, Nagashima KA, Cayanan C, Maddon PJ, Koup RA, Moore JP, Paxton WA: HIV-1 entry into CD4+ cells is mediated by the chemokine receptor CC-CKR5. Nature 1996, 381:667-673.

19. Deng H, Liu R, Ellmeir W, Choe S, Unutmaz D, Burkhart M, Di Marzio P, Marmon S, Sutton RE, Hill CM, Davis CB, Peiper SC, Schall TJ, Littman DR, Landau NR: Identification of a major co-receptor for primary isolates of HIV-1. Nature 1996, 381:661-666.

20. Berger EA, Murphy PM, Farber JM: Chemokine receptors as HIV-1 coreceptors:Roles in viral entry, tropism, and disease. Annual Review of Immunology 1999, 17:657-700.

21. Connor Rl, Sheridan KE, Ceradini D, Choe S, Landau NR: Change in coreceptor use correlates with disease progression in HIV-1-infected individuals. J Exp Med 1997, 185:621-628.

22. Bjorndal A, Deng HK, Jansson M, Fiore JR, Colognesis C, Karlsson A, Albert J, Scarlatti G, Littman DR, Fenyo EM: Coreceptor usage of primary human immunodeficiency virus type 1 isolates varies according to biological phenotype. J Virol 1997, 71:7478-7487. 
23. Shankarappa R, Margolick JB, Gange SJ, Rodrigo AG, Upchurch D, Farzadegan H, Gupta P, Rinaldo CR, Learn GH, He X, Huang XL, Mullins الJ: Consistent viral evolutionary changes associated with the progression of human immunodeficiency virus type 1 infection. J Virol 1999, 73:10489-10502.

24. Scarlatti G, Tresoldi E, Bjorndal A, Fredriksson R, Colognesi C, Deng HK, Malnati MS, Plebani A, Siccardi AG, Littman DR, Fenyo EM, Lusso P: In vivo evolution of HIV-1 co-receptor usage and sensitivity to chemokinemediated suppression. Nat Med 1997, 3:1259-1265.

25. Tasca S, Ho SH, Cheng-Mayer C: R5X4 viruses are evolutionary, functional, and antigenic intermediates in the pathway of a simianhuman immunodeficiency virus coreceptor switch. J Virol 2008 , 82:7089-7099.

26. Philpott SM: HIV-1 coreceptor usage, transmission, and disease progression. Curr HIV Res 2003, 1:217-227

27. Willett BJ, McMonagle EL, Ridha S, Hosie MJ: Differential utilization of CD134 as a functional receptor by diverse strains of feline immunodeficiency virus (FIV). J Virol 2006, 80:3386-3394.

28. Shimojima M, Miyazawa T, Ikeda Y, McMonagle EL, Haining H, Akashi H, Takeuchi Y, Hosie MJ, Willett BJ: Use of CD134 as a primary receptor by the feline immunodeficiency virus. Science 2004, 303:1192-1195.

29. de Parseval A, Chatterji U, Sun P, Elder JH: Feline immunodeficiency virus targets activated CD4+ T cells by using CD134 as a binding receptor. Proc Natl Acad Sci USA 2004, 101:13044-13049.

30. Willett BJ, Hosie MJ, Neil JC, Turner JD, Hoxie JA: Common mechanism of infection by lentiviruses. Nature 1997, 385:587.

31. Willett BJ, Picard L, Hosie MJ, Turner JD, Adema K, Clapham PR: Shared usage of the chemokine receptor CXCR4 by the feline and human immunodeficiency viruses. J Virol 1997, 71:6407-6415.

32. Poeschla EM, Looney DJ: CXCR4 requirement for a nonprimate lentivirus:heterologous expression of FIV in human, rodent and feline cells. J Virol 1998, 72:6858-6866.

33. Richardson J, Pancino G, Leste-Lasserre T, Schneider-Mergener J, Alizon M, Sonigo $P$, Heveker N: Shared usage of the chemokine receptor CXCR4 by primary and laboratory-adapted strains of feline immunodeficiency virus. J Virol 1999, 73:3661-3671

34. Egberink HF, De Clercq E, Henson G, Balzarini J, Horzinek MC, Schols D: The bicyclam AMD3100, a selective antagonist of the human chemokine receptor CXCR4, inhibits feline immunodeficiency virus (FIV) replication in vitro. Fourth International Feline Retrovirus Research Symposium 1998, A3.3:26.

35. Willett BJ, Cannon CA, Hosie MJ: Upregulation of surface feline CXCR4 expression following ectopic expression of CCR5: implications for studies of the cell tropism of feline immunodeficiency virus. J Virol 2002, 76:9242-9252.

36. Willett BJ, Hosie MJ: Chemokine receptors and co-stimulatory molecules: Unravelling feline immunodeficiency virus infection. Vet Immunol Immunopathol 2008, 123:56-64

37. Willett BJ, McMonagle EL, Bonci F, Pistello M, Hosie MJ: Mapping the domains of CD134 as a functional receptor for feline immunodeficiency virus. J Virol 2006, 80:7744-7747.

38. Willett BJ, McMonagle EL, logan N, Schneider P, Hosie MJ: Enforced covalent trimerisation of soluble feline CD134 (OX40)-ligand generates a functional antagonist of feline immunodeficiency virus. Mol Immunol 2009, 46:1020-30

39. Willett BJ, McMonagle EL, logan N, Spiller OB, Schneider P, Hosie MJ: Probing the interaction between the feline immunodeficiency virus and CD134 using a novel monoclonal antibody 7D6 and CD134L (OX40L). J Virol 2007, 81:9665-9679.

40. Willett Brian J, Hosie Margaret J: The Felid Immunodeficiency Viruses: Viral Cell Tropism and the Pathogenesis of Feline AIDS. In Lentiviruses and Macrophages Edited by: Moira Desport. Norfolk: Caister Academic Press; 2010:231-250

41. Hosie MJ, Willett BJ, Klein D, Dunsford TH, Cannon C, Shimojima M, Neil JC, Jarrett O: Evolution of replication efficiency following infection with a molecularly cloned feline immunodeficiency virus of low virulence. Virol 2002, 76:6062-6072

42. Kraase M, Sloan R, Klein D, logan N, McMonagle L, Biek R, Willett BJ, Hosie MJ: Feline immunodeficiency virus env gene evolution in experimentally infected cats. Vet Immunol Immunopathol 2010, 134:96-106
43. Dubridge RB, Tang P, Hsia HC, Leong PM, Miller JH, Calos MP: Analysis of mutation in human cells by using an Epstein-Barr virus shuttle system. Mol Cell Biol 1987, 7:379-387.

44. Pear WS, Nolan GP, Scott ML, Baltimore D: Production of high-titer helper-free retroviruses by transient transfection. Proc Natl Acad Sci USA 1993, 90:8392-8396

45. Miyazawa TM, Furuya T, Itagaki S, Tohya Y, Takahashi E, Mikami T: Establishment of a feline T-lymphoblastoid cell line highly sensitive for replication of feline immunodeficiency virus. Arch Virol 1989, 108:131-135.

46. Connor RI, Chen BK, Choe S, Landau NR: Vpr is required for efficient replication of human immunodeficiency virus type-1 in mononuclear phagocytes. Virology 1995, 206:935-944

47. Hosie MJ, Dunsford T, Klein D, Willett BJ, Cannon C, Osborne R, Macdonald J, Spibey N, Mackay N, Jarrett O, Neil JC: Vaccination with inactivated virus but not viral DNA reduces virus load following challenge with a heterologous and virulent isolate of feline immunodeficiency virus. $J$ Virol 2000, 74:9403-9411.

48. Cheney CM, Rojko JL, Kociba GJ, Wellman ML, Di Bartola SP, Rezanka LJ, Forman L, Mathes LE: A feline large granular lymphoma and its derived cell line. In Vitro Cell Dev Biol 1990, 26:455-463.

49. Willett BJ, McMonagle EL, logan N, Samman A, Hosie MJ: A single site for $\mathrm{N}$-linked glycosylation in the envelope glycoprotein of feline immunodeficiency virus modulates the virus-receptor interaction. Retrovirology 2008, 5:77

50. de Parseval A, Grant CK, Sastry KJ, Elder JH: Sequential CD134-CXCR4 interactions in feline immunodeficiency virus (FIV): soluble CD134 activates FIV Env for CXCR4-dependent entry and reveals a cryptic neutralization epitope. J Virol 2006, 80:3088-3091.

51. de Parseval A, Chatterji U, Morris G, Sun P, Olson AJ, Elder JH: Structural mapping of $C D 134$ residues critical for interaction with feline immunodeficiency virus. Nat Struct Mol Biol 2004, 12:60-66

52. McKnight A, Clapham PR: Immune escape and tropism of HIV. Trends Microbiol 1995, 3:356-361.

53. McKnight A, Weiss RA, Shotton C, Takeuchi Y, Hoshino H, Clapham PR: Change in tropism upon immune escape by human immunodeficiency virus. J Virol 1995, 69:3167-3170.

54. Quakkelaar ED, Beaumont $T$, van Nuenen AC, van Alphen FP, BoeserNunnink BD, 't Wout AB, Schuitemaker $H$ : T cell line passage can select for pre-existing neutralization-sensitive variants from the quasispecies of primary human immunodeficiency virus type- 1 isolates. Virology 2007, 359:92-104

55. English RV, Johnson CM, Gebhard DH, Tompkins MB: In vivo lymphocyte tropism of feline immunodeficiency virus. J Virol 1993, 67:5175-5186.

56. Dean GA, Reubel GH, Moore PF, Pedersen NC: Proviral burden and infection kinetics of feline immunodeficiency virus in lymphocyte subsets of blood and lymph node. J Virol 1996, 70:5165-5169.

57. Kimata JT, Gosink JJ, KewalRamani VN, Rudensey LM, Littman DR, Overbaugh J: Coreceptor specificity of temporal variants of simian immunodeficiency virus Mne. J Virol 1999, 73:1655-1660.

58. Kitchen CM, Philpott S, Burger H, Weiser B, Anastos K, Suchard MA Evolution of human immunodeficiency virus type 1 coreceptor usage during antiretroviral Therapy: a Bayesian approach. J Virol 2004, 78:11296-11302.

59. Stalmeijer EH, Van Rij RP, Boeser-Nunnink B, Visser JA, Naarding MA, Schols $D$, Schuitemaker $H$ : In vivo evolution of $\times 4$ human immunodeficiency virus type 1 variants in the natural course of infection coincides with decreasing sensitivity to CXCR4 antagonists. J Virol 2004, 78:2722-2728.

60. Hu QX, Barry AP, Wang ZX, Connolly SM, Peiper SC, Greenberg ML: Evolution of the human immunodeficiency virus type 1 envelope during infection reveals molecular corollaries of specificity for coreceptor utilization and AIDS pathogenesis. J Virol 2000, 74:11858-11872

61. Lauren A, Vodros D, Thorstensson R, Fenyo EM: Comparative studies on mucosal and intravenous transmission of simian immunodeficiency virus (SIVsm): evolution of coreceptor use varies with pathogenic outcome. JGV 2006, 87:581-594.

62. Nabatov AA, Pollakis G, Linnemann T, Kliphius A, Chalaby MI, Paxton WA Intrapatient alterations in the human immunodeficiency virus type 1 gp120 V1V2 and V3 regions differentially modulate coreceptor usage, virus inhibition by CC/CXC chemokines, soluble CD4, and the b12 and 2G12 monoclonal antibodies. J Virol 2004, 78:524-530. 
63. Siebelink KHJ, Huisman W, Karlas JA, Rimmelzwaan GF, Bosch ML, Osterhaus ADME: Neutralization of feline immunodeficiency virus by polyclonal feline antibody: simultaneous involvement of hypervariable regions 4 and 5 of the surface glycoprotein. J Virol 1996, 69:5124-5127.

64. Bendinelli M, Pistello M, Del Mauro D, Cammarota G, Maggi F, Leonildi A, Giannecchini S, Bergamini C, Matteucci D: During readaptation in vivo, a tissue culture-adapted strain of feline immunodeficiency virus reverts to broad neutralization resistance at different times in individual hosts but through changes at the same position of the surface glycoprotein. J Virol 2001, 75:4584-4593.

65. Giannecchini S, Matteucci D, Ferrari A, Pistello M, Bendinelli M: Feline immunodeficiency virus-infected cat sera associated with the development of broad neutralization resistance in vivo drive similar reversions in vitro. J Virol 2001, 75:8868-8873.

66. Samman A, logan N, McMonagle EL, Ishida T, Mochizuki M, Willett BJ, Hosie MJ: Neutralisation of feline immunodeficiency virus by antibodies targeting the V5 Loop of Env. J Gen Virol 2010, 91:242-9.

67. Pancino G, Fossati I, Chappey C, Castelot S, Hurtrel B, Moraillon A, Klatzmann D, Sonigo P: Structure and variations of feline immunodeficiency virus envelope glycoproteins. Virology 1993 192:659-662.

doi: $10.1186 / 1742-4690-7-38$

Cite this article as: Willett et al., Modulation of the virus-receptor interaction by mutations in the $\mathrm{V} 5$ loop of feline immunodeficiency virus (FIV) following in vivo escape from neutralising antibody Retrovirology 2010, 7:38

Submit your next manuscript to BioMed Central and take full advantage of:

- Convenient online submission

- Thorough peer review

- No space constraints or color figure charges

- Immediate publication on acceptance

- Inclusion in PubMed, CAS, Scopus and Google Scholar

- Research which is freely available for redistribution

Submit your manuscript at www.biomedcentral.com/submit
Ciomed Central 